\title{
TRYPANOSOMA CRUZI: AVIRULENCE OF THE PF STRAIN TO CALLITHRIX MARMOSETS*
}

\author{
Humberto Menezes * *
}

Callithrix jacchus geoffroy marmosets (Humbo/dt 1812) were injected once subcutaneous/y with 10.000 parasites $/ g$ body weight and followed for a period of six months. The PF strain of Trypanosoma cruzi was used. Follow-up was done through blood cultures, xenodiagnosis, serological tests, and ECG. A small number of normal animals served as control.

\section{INTRODUCTION}

Blanchard ${ }^{1}$, Laveran ${ }^{6}$, Brumpt $^{2}$, Mayer and Rocha Lima ${ }^{9}$, and recently, other investigators have reported that animals which survived a virulent infection with Trypanosoma cruzi became resistant to a subsequent challenge with this parasite.

Different procedures have been utilized over the years by several investigators searching for protection against further virulent $T$. cruzi infections: injection of low-virulence parasites (Norman and Kagan ${ }^{22}$; Kagan and Norman ${ }^{5}$; Marr and $\mathrm{Pike}^{8}$; Seah and Marsden ${ }^{26}$ ); injection of killed parasites (Soltys ${ }^{28}$; Neal and John$\operatorname{son}^{21}$ ); of flagellate fractions (Segura, Cura, Paulone, Vasquez and Cerisola ${ }^{27}$ ); of molecular fractions of cells from immunized hosts (Lemos and Menezes ${ }^{7}$ ); and of subcellular fractions of related parasites (Grymberg, NeriGuimarães, Castro and Oliveira Lima ${ }^{4}$ ).

Injection of low-virulence parasites (Pizzi and $\operatorname{Prager}^{24}$ ) or of a virulent strain, immediately followed by treatment (Pizzi ${ }^{25}$ ) seems to be the most effective technique so far emplo- yed to obtain efficient protection. These observations have been confirmed by immunological techniques, which demonstrate that the infected animals develop antibodies and immunologically competent cells against the flagellates. A problem posed by this technique is the danger of infection with the low-virulence protozoa, which, although low virulent, could induce patent parasitemia in the injected animals. An additional problem is the mandatory treatment of all animals injeted with a virulent strain.

Injection of parasitic fractions or other molecular derivatives of the infected animals opens a promissing new field in trypanosomiasis research, but will not be discussed here. My discussion will be limited to the avirulence of a strain of $T$. cruzi i.e. a trypanosoma unable to induce disease or parasitemia, or to produce positive serological tests when injected in a suitable dose and by an adequate route. In 1968,1 described such a parasite (Menezes ${ }^{10}$ ) as a probable misture of mutants of the $y$ strain, reported by Pereira da Silva an Nussenzweig $^{23}$ (as being highly virulent to mice. In a

This work was supported by Grant SIP $08 / 42$ of the Conselho Nacional de Desenvolvimento Cientifico e Tecnologico (CNPq).

** Departamento de Genética, Faculdade de Medicina de Ribeirão Preto, USP, 14.100 - Ribeirão Preto - São Paulo - Brasil.

Submitted to publication on $\mathbf{5 . 2 2 . 7 5}$ 
paper coauthored by Albuquerque (Menezes and Albuquerque ${ }^{13}$ ) this strain was named $P F$, and it has been my objective ever since to demonstrate its avirulence, emphasizing at the same time that, due to its live vaccine nature, it should not be used indiscriminately.

In 1970 (Menezes $^{12}$ ), I described the first examples of animals injected with a very high dose of parasites which, although they presented positive blood cultures, gave negative results when inoculated into baby mice in culture form. The study presented here was carried out on Callithrix jacchus geoffroy marmosets, and concerns the tests performed before vaccination and throughout the six month period following injection of the avirulent strain.

\section{MATERIALS AND METHODS}

\section{Animals}

Sixteen Callithrix jacchus geoffroy marmosets (Humboldt 1812) -9 males and 7 females - were vaccinated once subcutaneously (Fig. 1) Mean weight at the beginning of the experiment was $316.3 \pm 79.5 \mathrm{~g}$ for the males, and $331.7 \pm$ $37.7 \mathrm{~g}$ for the females. The controls were 8 similar marmosets, 5 males with a mean weight of $281.8 \pm 72.2 \mathrm{~g}$, and 3 females with a mean weight of $384.0 \pm 72.2 \mathrm{~g}$. All animals were trapped in their natural habitat (all at the same location) and were housed in cages containing one couple each whenever possible. All animals were kept under the same environmental and nutritional conditions. The diet consisted mainIy of fruit (banana, papaya and oranges), with protein provided by non-fat milk and dehydrated soups (meat or chicken with vegetables) mixed with bread. All animals received a vitamin supplement once a week by oral route 110.000 IU vitamin A, 2000 IU vitamin D, and $100 \mathrm{mg}$ vitamin $C \%$, and had free access to water.

\section{Vaccine}

The vaccine used was a suspension of the $P F$ strain of $T$. cruzi harvested according to a personal modification of the Nakamura ${ }^{20}$ technique. Uncoagulated and unfiltered Warren medium (Warren ${ }^{30}$ ) was put into cellophane bags, which were placed into Erlenmeyer's flasks containing twice the amount of PBS solution, $\mathrm{pH}$ 7.2. The material was sterilized in an autoclave for 15 minutes at $115^{\circ} \mathrm{C}$. The parasite cultures, 14 days old, were rinsed twice in saline solution and resuspended in sterile saline after centrifugation at $1500 \mathrm{rpm}$. The flagellate suspension contained $2 \times 10^{7}$ parasites $/ \mathrm{ml}$, with about $80 \%$ mobile forms, and $0.26 \%$ trypomastigote forms lover 5000 parasites were counted on five different slides stained with Giemsa).

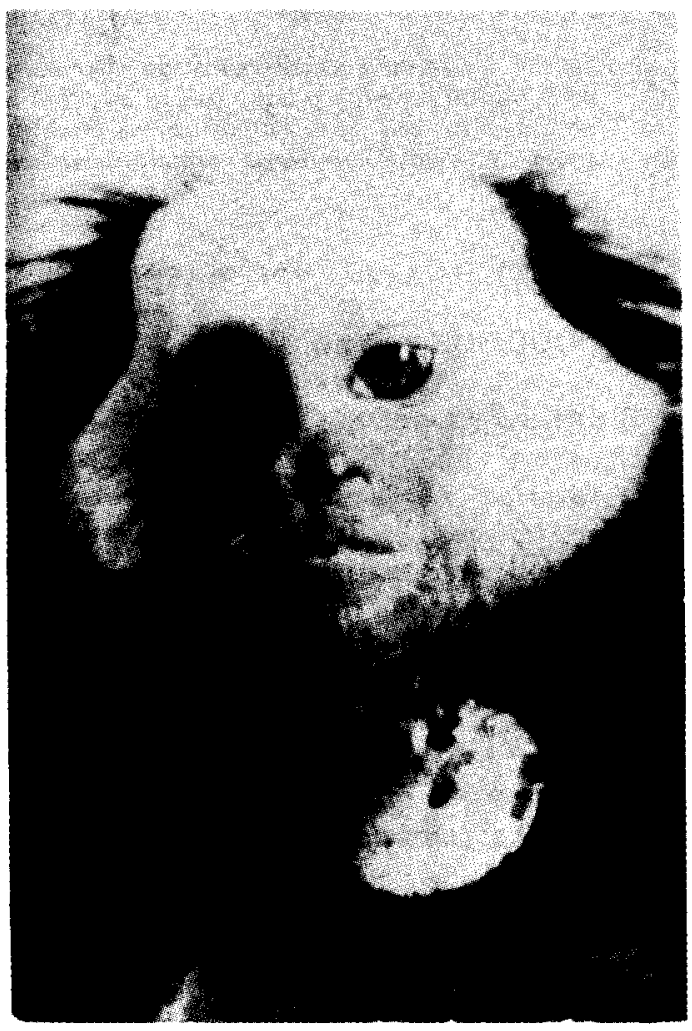

Fig. 1 - Callithrix jacchus geoffroyi (Humboldt, 1812)

Each animal was injected subcutaneously with 10,000 parasites/g body weight shortly after preparation of the vaccine. An ECG each marmoset was taken once before, and several times after, vaccination. The test was performed in a FUNBEC apparatus, using the 12 standard leads. Prior to the test, each animal was injected subcutaneously with $0.1 \mathrm{ml}$ Inoval (Johnson \& Johnson Laboratories) (Fentanil, $0.5 \mathrm{mg}$; Droperidol, $25 \mathrm{mg}$; sterile vehicle, qsp $10 \mathrm{ml}$ ). 


\section{Blood Cultures}

Hemocultures were carried out in tubes (2 per animal) containing $5 \mathrm{ml}$ original Warren medium (Warren $\left.{ }^{30}\right)$. The cultures were examined 30 and $\mathbf{4 5}$ days later. This test was also performed before and after vaccination.

\section{Xenodiagnosis}

This test was carried out before and after vaccination of the animals. Six nymphs, 5th instar, of Rhodnius neglectus were used for each test. The triatominae were examined 30 and 45 days after the insects fed on marmoset blood. The latest examination was always carried out on the sediment of a pool of the intestinal contents of the remaining insects, after suspension in saline solution and centrifugation at $1500 \mathrm{rpm}$.

\section{Indirect Hemagg/utination Test (IHT)}

This test was carried out using a filter paper blood smear, following the technique described by Souza and Camargo ${ }^{29}$ for the immunofluorescence test. The smears were kept in a deep freezer until the time of the test. The eluates were employed according to the method of Camargo et al. ${ }^{3}$ afeter inactivation at $56^{\circ} \mathrm{C}$ for 30 minutes, and centrifugation at $1500 \mathrm{rpm}$ for 15 minutes. The sensitized red cells were kindly supplied by the laboratory of Dr. M.E. Camargo (Instituto de Medicina Tropical, USP, São Paulo).

\section{RESULTS}

\section{Body Weight}

Table I shows that both vaccinated and control animals lost weight during the 6 months duration of the experiment.

\section{TABLE I}

Body Weight of Experimental and Control Groups

\begin{tabular}{lccccccccc}
\hline Group & $\begin{array}{c}\text { Total } \\
\text { Number }\end{array}$ & Sex & \multicolumn{2}{c}{ Initial Weight } & & Final Weight & Weight Change Total \\
$(\%)$
\end{tabular}

\section{ECG}

This test revealed abnormalities for only a few animals. The reader is referred to Table II where the results have been summarized. The cardiologist who collaborated in this investigation concluded that no essential abnormalities were found in the experimental animals after vaccination. No positive serological tests were obtained for any animal showing ECG abnormalities.

\section{Xenodiagnosis}

Table 111 summarizes the xenodiagnosis results obtained for experimental and control animals. On the average, two tests were performed before, anf 5 after, vaccination of the experimental group. An average of 4 xenodiagnoses were performed for the control during the 6 months of observation. The results were always negative for both groups.

\section{Blood Cultures}

About 2 hemocultures were performed per each experimental animal before vaccionation, and about 3 after vaccination. About 4 blood 
cultures per animal were performed for the controls throughout the 6 months of observa- tion. As in the preceding test, all results were negative (Table III).

TABLE II

ECG Results for the Experimental and Control Groups

\begin{tabular}{|c|c|c|c|c|c|c|c|}
\hline \multicolumn{2}{|c|}{ Marmosets } & \multicolumn{4}{|c|}{ Experimental } & \multicolumn{2}{|c|}{ Control } \\
\hline $\begin{array}{l}\text { Identifi- } \\
\text { cation }\end{array}$ & Sex & $\begin{array}{l}\text { Before Vac- } \\
\text { cination }\end{array}$ & & $\begin{array}{l}\text { After vac- } \\
\text { cination }\end{array}$ & & $\begin{array}{r}\text { During the } 6 \\
\text { observat }\end{array}$ & nths' \\
\hline 5 & M & LAVB 1/B & (1) & LAVB $1 / 2 B$ & (3) & & \\
\hline 6 & M & $\mathbf{N}$ & (1) & $\mathbf{N}$ & (4) & & \\
\hline 12 & $M$ & LAVBB 1st & (1) & $\mathbf{N}$ & (4) & & \\
\hline 13 & M & $\mathbf{N}$ & (1) & $\mathbf{N}$ & (4) & & \\
\hline 14 & $F$ & $\mathbf{N}$ & (1) & $\mathbf{N}$ & (4) & & \\
\hline 37 & $F$ & $\mathbf{N}$ & (1) & $\mathbf{N}$ & (4) & & \\
\hline 22 & M & $\mathbf{N}$ & (1) & $\mathbf{N}$ & (3) & & \\
\hline 25 & $\mathbf{F}$ & $\mathbf{N}$ & (1) & $\mathbf{N}$ & (3) & & \\
\hline 30 & $F$ & $\mathbf{N}$ & (1) & $\mathbf{N}$ & (3) & & \\
\hline 31 & $M$ & $\mathbf{N}$ & (1) & $\mathbf{N}$ & (4) & & \\
\hline 32 & $F$ & RAVB $1 / 2 B$ & (1) & RAVB 1/2B & (4) & & \\
\hline 33 & $F$ & $\mathbf{N}$ & (1) & $\mathbf{N}$ & (3) & & \\
\hline 34 & $F$ & $\mathbf{N}$ & (1) & $\mathbf{N}$ & (3) & & \\
\hline 35 & $\mathbf{M}$ & $\mathbf{N}$ & (1) & $\mathbf{N}$ & (3) & & \\
\hline 44 & $M$ & $\mathbf{N}$ & (1) & $\mathbf{N}$ & (3) & & \\
\hline 99 & $M$ & $\mathbf{N}$ & (1) & $\mathbf{N}$ & (3) & & \\
\hline 17 & M & & & & & $\mathbf{N}$ & (3) \\
\hline 19 & $F$ & & & & & Sinusal rythm & (2) \\
\hline 26 & M & & & & & $\mathbf{N}$ & (4) \\
\hline 47 & $M$ & & & & & $\mathbf{N}$ & (3) \\
\hline 4 & M & & & & & RVBB & (3) \\
\hline 7 & $F$ & & & & & $\mathrm{~N}$ & (2) \\
\hline 11 & M & & & & & $\mathbf{N}$ & (2) \\
\hline 8 & $F$ & & & & & $\mathbf{N}$ & (2) \\
\hline
\end{tabular}

LAVB 1/2B = Left anterior ventricular branch hemi-block

$\mathrm{N}=$ normal

LAVBB 1 st $=$ Left anterior ventricular branch block - first degree. $(1)=$ Number of tests

RAVB $1 / 2 B=$ Right anterior ventricular branch hemi-block.

performed

\section{Indirect Hemagglutination Test (IHT)}

Before vaccination the IHT was negative in $100 \%$ of the marmosets. After vaccination, 93.8\% of the tests remained negative while only of 16 animals $(6.2 \%)$ became serologically positive, but with all the parasitological tests negative (Table (II), i.e. the two positive tests of the experimental group belonged to the same animal.
The 4 doubtful tests represent the results of 3 different marmosets. When the tests were repeated for 2 of the animals the results were negative. The 2 positive results of the control group belonged to two different animals. In one of them, 4 tests carried out later on gave negative results and in the other a positive test was obtained after repetition of a doubtful result. The other 4 doubtful results in the group were from 3 other animals. When the tests were repeated, all results became negative. 


\section{DISCUSSION}

The main objective of this study was to demonstrate the avirulence of the $P F$ strain of $T$. cruzi to marmosets, when administered in appropriate doses and by an advantageous route, as is the case with any other type of vaccine, live or not.

The only reliable means of detection of presumptive trypanosomiasis available to us at present are those utilized in this study. Until the time when an infallible diagnostic test for trypanosoma infections is developed we must be satisfied with what parasitologists the world over consider available evidence of trypanosomiasis, i.e. positive xenodiagnosis, blood culture, serological tests and, whenever possible, histopathological findings. Each of these tests has its limitations when performed separately, but the chances of diagnosis increase when they are employed together and repeated more than once.

Considering these arguments and on the basis of the present experiment, I can conclude once more that, when utilized adequately, the $P F$ live vaccine of $T$. cruzi is avirulent.

I have already demonstrated that no infection could be detected in different animal species, including man, after the proper use of the PF strain of $T$. cruzi (Menezes ${ }^{11}$; Menezes and Ribeiro ${ }^{14}$; Menezes ${ }^{15,16,17,18,19}$ ).

\section{RESUMO}

Calitricideos da espécie C. jacchus geoffrovi (Humboldt, 1812) vacinados uma úniva vez, subcutaneamente, com 10.000 parasitas $/ g$ de peso corporal, foram seguidos durante um periodo de seis meses. Usou-se como vacina a cepa PF de T. cruzi.

O seguimento foi feito através de hemoculturas, xenodiagnósticos, testes serológicos $\boldsymbol{e}$ ECG. Um pequeno número de animais serviu como controle normal.

\section{ACKNOWLEDGMENTS}

I am grateful to Dr. F. Vicchi (Faculty of Medicine of Ribeirão Pretol who analyzed the ECG tests.

\section{REFERENCES}

1. BLANCHARD, M. 1912. Marche de l'infec- tion à Schyzotripanum cruzi chez le cobaye et la souris. Bulletin de la Societé de Pathologie Exotique 5 , 598-599.

2. BRUMPT, E. 1913. Immunité partielle dans les infections à Trypanosoma cruzi; transmission de ce trypanosome par Cimex rotundatus. Rôle regulateur des hôtes intermediaires. Passage à travers la peau. Bulletin de la Societé de Pathologie Exotique 6, 172-176.

3. CAMARGO, M.E., HOSHINO, S. AND SIQUEIRA, G.R.V. 1973. Hemagglutination with preserved, sensitized cells, practical test for routine seroloçical diagnosis of American trypanosomiasis. Revista do Instituto de Medicina Tropical de São Paulo 15, 81-85.

4. GRYMBERG, N., NERY-GUIMARÃES, F., CASTRO, F.T. AND OLIVEIRA LIMA, A. 1977. The effect of the injection of ribosomes and RNA from Crithidia fasciculata on the experimental infection of mice by Trypanosoma cruzi. Transactions of the Royal Society of Tropical Medicine and Hygiene 71, 35-36.

5. KAGAN, I.G., AND HORMAN, L. 1961. Immunologic studies on Trypanosoma cruzi. III Duration of acquired immunity in mice initially infected with a North American strain of Trypanosoma cruzi. Journal of Infections Diseases 108, 213-217.

6. LAVERAN, A. 1912. Essais d'immunisation contre des trypanosomes pathogens. Bulletin de la Societé de Pathologie Exotique 5, 877-882.

7. LEMOS, M.V.F. AND MENEZES, $H$. 1978. The effect of an immune RNA (RNAi) against Trypanosoma cruzi infection in mice. Tropenmedizin und Parasitologie 29, 119-126.

8. MARR, J.S. AND PIKE, E.H. 1967. The protection of mice by "Corpus Chris$\mathrm{ti}^{\prime \prime}$ strain of Trypanosoma cruzi when challenged with "Brazil" strain. Journal of Parasitology 53, 657-659.

9. MAYER, M. AND ROCHA LIMA, H. 1914. Zum Verhalten von Schizotrypanum cruzi im Warmblutern und Arthropoden. Archiv für Schiffs und Tropenhygiene 18, 101-136. in PIZZI, T. 1961, op. cit.

10. MENEZES, H. 1968. Protective effect of an avirulent (cultivated) strain of 
Trypanosoma cruzi against experimental infection in mice. Revista do Instituto de Medicina Tropical de São Paulo 10, 1-14.

11. MENEZES, H. 1969. Active immunization of dogs with a non virulent strain of Trypanosoma cruzi. Revista do Instituto de Medicina Tropical de São Paulo 11, 258-263.

12. MENEZES, H. 1970. I. The avirulent of the cultivated $Y$ strain of Trypanosoma cruzi. Revista do Instituto de Medicina Tropical de São Paulo 12, 64-68.

13. MENEZES, $H$. AND ALBUOUEROUE, $R$. D.R. 1970. Imunização de camundongos com "vacina" viva avirulenta de Trypanosoma cruzi. IV. Variação do meio de cultura. Revista da Sociedade Brasileira de Medicina 4, 69-74.

14. MENEZES, H. AND RIBEIRO, R.D. 1972. The avirulence of the cultivated "PF" strain of Trypanosoma cruzi. $V$. The evaluation of parasitologic tests after vaccination of different animal species. Revista da Sociedade Brasileira de Medicina Tropical 6, 41-48.

15. MENEZES, H. 1972. The avirulence of the cultivated $Y$ strain of Trypanosoma cruzi. IV. The effect of immunosuppressive agents in mice. Revista da Sociedade Brasileira de Medicina Tropical 5, 213-235.

16. MENEZES, H. 1974. The avirulence of the cultivated PF strain of Trypanosoma cruzi. VI. The effect of antilymphocy. tic serum in dogs. Revista da Sociedade Brasileira de Medicina Tropical 8, 252-257.

17. MENEZES, H. 1975. The un-infectivity of the PF cultivated strain of Trypanosoma cruzi to mice. An evaluation through a one year period by blood cultures and histopathology. Revista da Sociedade Brasileira de Medicina Tropical 9, 1.5.

18. MENEZES, H. 1976. A avirulência, para camundongos, da cepa PF do Trypanosoma cruzi. Avaliação por xenodiagnóstico, cultura de vísceras e histapatologia escalonada. Revista da Associação Médica Brasileira 22, 111. 114.

19. MENEZES, H. 1976. A vacinação de seres humanos com a vacina viva avirulenta de Trypanosoma cruzi. Seguimento durante cinco anos dos dois primeiros casos. Revista da Associação Médica Brasileira 22, 252-255.

20. NAKAMURA, M. 1967. Cultivation of Trypanosoma cruzi in a protein-free dialysa et medium. Proceedings of the Socie $y$ of Experimental Biology and Medicine 125, 779-780.

21. NEAL, R.A. AND JOHNSON, P. 1977. Immunization against Trypanosoma cruzi using killed antigens and with saponin as adjuvant. Acta Tropica 34, 87-96.

22. NORMAN, L. AND KAGAN, G. 1960. Immunologic studies on Trypanosoma cruzi. II. Acquired immunity in mice infected with avirulent American strain of Trypanosoma cruzi. Journal of Infectious Diseases 107, 168-174.

23. PEREIRA DA SILVA, L.H. AND NUSSENZWEIG, V. 1953. Sobre uma cepa de Trypanosoma cruzi altamente virulenta para o camundongo branco. Folia Clinica e Biologica 20, 191-208.

24. PIZZI, T. AND PRAGER, R. 1952. Imunidad a la sobreinfección inducida mediante cultivos de Trypanosoma cruzi a virulencia atenuada. (Comunicación preliminar). Boletin de informaciones parasitarias chilenas 7, 2021.

25. PIZZI, T.P. 1961. Imunologia de la enfermedad de Chagas: Estado actual del problema. Bole in de la Oficina Sanitaria Panamericana 51, 450-464.

26. SEAH, B. AND MARSDEN, P.D. 1969. The protection of mice against a virulent strain of Trypanosoma cruzi by previous inoculation with an avirulent strain. Annals of Tropical Medicine and Parasitology 63, 211214.

27. SEGURA, E., CURA, E.N., PAULONE, I., VASQUEZ, C. AND CERISOLA, J.A. 1974. Antigenic makeup of subcellular fractions of Trypanosoma cruzi. Journal of Protozzology 21, 571.574.

28. SOLTYS, M.A. 1964. Immunity in trypanosomiasis. $\mathrm{V}$. Immunization of animals with dead trypanosomes. Parasitology 54, 585-591.

29. SOUZA, S.L. AND CAMARGO, M.E. 1966. The use of filter paper blood smear in a practical fluorescent test 
for American trypanosomiasis serodiagnosis. Revista do Instituto de Medicina tropical de São Paulo 8, 225-258.

30. WARREN, L.G. 1960. Metabolism of
Schizotrypanum cruzi, Chagas.

Effect of culture age and substrate concentration on respiratory rate. Journal of Parasitology 46, 529. 539. 